\title{
Expatriate Selection: The Key To International Success
}

Jifu Wang, (E-mail: wangj@ vic.uh.edu), University of Houston, Victoria

Charles Bullock, (E-mail: BullockC@vic.uh.edu), University of Houston, Victoria Sharon Oswald, (E-mail: Oswald@ @usiness.auburn.edu), Auburn University

\begin{abstract}
The types of criteria used to evaluate individuals' success in expatriate assignments and variables, which could represent expatriates' knowledge skills and abilities (KSAs), were investigated in this study. The four most common criteria are (a) technical competencies; (b) human relational skills; (c) spouse and family adaptability; and (d) desirability to serve overseas. Another attempt was made to understand the relationships between firm's selection strategies and expatriate success. Success was viewed from a multidimensional perspective. In addition, the tasks and responsibilities of expatriates vary by company, by industry, and by country. A contingency approach for selection was discussed briefly.
\end{abstract}

\section{Introduction}

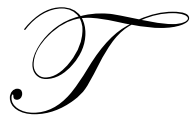

he market liberalization and privatization policies of emerging economic regions throughout the world have led to a marked increase in the amount of US foreign direct investment (Isobe, Makino, \& Montgomery, 2000). The U.S. Commerce Department estimated that the US had a total foreign investment of almost one-half trillion dollars at the end of 1992 (Phatak, 1995), only to see it triple to $\$ 95$ billion three years later (Zachary, 1996). The rise in international operations places extra demands on all facets of a business enterprise. However, one area of a company that is especially challenged by these rising pressures of internationalization is human resources. The pressure to adequately and appropriately staff host country operations is of paramount concern as expatriates today are playing an increasing role in the implementation of a global company strategy and long-term competitiveness. Interestingly, the rate of premature returns on the part of US expatriates leads one to believe that many multinationals have done a poor job in their selection of individuals for overseas assignments (Black, 1988; Lanier, 1979; Misa \& Fabricatore, 1979; Tung, 1981). Specifically, the failure rate of U.S. expatriates in their international assignments ranges from 10 to 45 percent at an estimated cost of between $\$ 50,000$ to $\$ 200,000$ per person (Black, Gregersen, Mendenhall, \& Stroh, 1999).

A review of the relevant literature over the past 20 years revealed a paucity of research on expatriate selection. Most of the studies conducted on the core elements of international human resource management (IHRM) have been focused on cultural adjustment and training. In this research we identify criteria for selecting the right individual for an overseas assignment.

\section{Significance of Expatriates}

The US expatriate population was estimated to have grown at 15\% to 20\% between 1992 and 1995(Beller, 1995). U.S. multinationals were estimated to send 100,000 American expatriates abroad each year at a corporate investment of \$1 million over four years per person (Engen, 1995). According to Laabs (1993), American relocations doubled from 1991 to only to double again by the year 2000. Torbiorn (1982) identified three functions that motivated global assignments: (1) control, (2) contact and coordination, and (3) the provision of special know-how in the local operations abroad. The appropriate individual should be able to function equally in each of these roles. In the control function, expatriates are utilized to ensure that operations are conducted in accordance with the ambitions of

Readers with comments or questions are encouraged to contact the authors via email. 
the parent company. Expatriates also perform the contact and coordination function between the parent corporation and its subsidiaries, for they know the company norms, people, values and ways of how operations are conducted. Thus they work as a liaison for evaluating and translating headquarters' information for international business units, and transmitting different kinds of information and feedback from local units to other parts of the organization. The third important role of the expatriates is that they can provide the subsidiary with such technological and/or administrative knowledge as the parent company considers crucial to the effective and efficient functioning of the strategic business unit (Kauppinen, 1994). Therefore, a primary strategic challenge for any multinational corporation is the selection of expatriates who can function effectively and efficiently in each of the three roles (Tung, 1984).

\section{False Assumptions and a Major Reason for Failure}

Careful research into the problems of premature return indicates that the list of reasons for expatriate failure is topped with selection problems (Black, et al., 1999; Fukuda \& Chu, 1994; Kobrin, 1989; Tung, 1981; 1982). Most multinationals select candidates for international assignments on the basis of their domestic track records, believing a good manager in New York or Los Angeles will be effective in Hong Kong or Tokyo. Such a culturally unrealistic perspective seems to be an important reason for the high expatriate failure rate (Giacalone \& Beard, 1994, pp. 628 - 629). Focusing on technical competence in the selection of expatriates is somewhat superficial (Baker \& Ivancevich, 1971). The belieft that managing in one country is the same as managing in another country, is as problematic as assuming that managing in one division is the same as managing in another division (Adler, 1995; Mendenhall \& Oddou, 1988).

Consequently, firms can increase the probability of successful adjustment through careful selection of candidates. Selection, however, should be based on personality profiles and other specific criteria other than purely technical skills (Mendenhall \& Wiley, 1994). Stone (1991) contended that U.S. "companies still do not recognize that international selection is considerably more complex than domestic selection" (p. 9). In other words, the overseas selection procedure is different from the domestic selection procedure. The tragedy is that the same selection process is employed most of the time (Stone, 1991).

\section{Analysis of Expatriate Job Structure}

Hays (1974) classified overseas job assignments into four major categories:

1. Chief executive officer: those expatriates whose responsibility is to oversee and direct the entire operation;

2. Structure reproducer or functional head: employees whose job is to establish functional departments in a foreign affiliate;

3. Trouble shooter: employees or "hired guns" whose function is to analyze and solve specific operational problems;

4. Operative employees: overseas employees, who act as element, or the rank and file members.

Each of these job structures requires varying degrees of contact with, knowledge of, and duration of stay in the foreign country. Usually, job assignments in the first two categories require more extensive interaction and contact with members of the local community and a longer stay in the foreign positions than job assignments in the last two categories. Thus, it would be appropriate to emphasize different specifications for selecting candidates for each of these job categories (Tung, 1981).

\section{Identification of Expatriate Selection Criteria}

The success of expatriate assignments unfortunately cannot be judged by successful domestic careers. (Tung, 1981). Most corporations use the same employee selection measures or criteria (Gatewood \& Feild 1998) for selecting for all job candidates with the same job title, although the performance requirements for these likely differ. Multinational companies (MNC) can maximize the likelihood of expatriates' success through appropriate selection programs that account for additional or specific performance dimensions created by the foreign environment (Black, Gregersen, \& Mendenhall, 1992). Since the dimensions comprising the performance construct for expatriate positions differ from that of performance in domestic positions, expatriate employees in an international environment 
need a somewhat different set of skills and abilities to accomplish the same job they performed successfully in a domestic environment.

A selection paradigm entails, at the very least, the identification of (1) variables or factors that are crucial to success on the job; (2) relationships between these different sets of variables, and (3) the weight that should be assigned to each factor in a given situation. It is especially crucial to identify the latter, because assignments, and hence selection, vary on the bases of the tasks to be performed and the environment to which the individual is sent. Different job assignments require varying degrees of contact with the local culture, which may be very different from the home culture. A selection paradigm has to take these situational variables into consideration. For this reason, the use of appropriate selection criteria should increase the likelihood that the organization will select a candidate who can be an effective expatriate. Those enterprises that consider a wide range of selection criteria in the selection decision process are more likely to select a candidate who can be successful in a culturally distant setting.

Some studies concluded that the most important factor in an overseas assignment is job ability (Hays, 1971; Newman, et al., 1978,), and such a unidimensional criterion, namely technical ability, continued to be dominant throughout the 1980's (Black, et al., 1991). This variable seems to be a measure of consistency in findings over the last two decades. Yet, the yardstick of technical competence captures only part of the expatriates' range of skills and necessary attributes, and may not even the essential ones. Attitudinal competencies are of paramount importance in global success (Marquart \& Engel, 1993). Shumsky outlined characteristics for potential expatriates: openmindedness, risk-taking, patience, flexibility, respect for the beliefs of others, and spousal communication. Thompson (1992) suggested additional factors such as emotional strength, family situation, and personality. Other researchers proposed that key characteristics for expatriate success were independence, sincerity, integrity, sense of justice, and technical knowledge (Baker \& Ivancevich, 1971).

Hays (1971) summarized four determinants of success in an expatriate position: job ability, relational ability, family situation, and language ability. Baliga and Baker (1985) identified technical skill, highly developed human empathy, and management qualities as the salient variables in expatriate effectiveness. Some other criteria discussed in the expatriate literature include determination, persistence (Chowanec \& Newstrom, 1991), tolerance for ambiguity (Heller, 1980), ability to cope with stress, patience, a sense of humor (Marquardt \& Engel, 1993), cultural flexibility, affect (Tucker, et al., 1985), and reading subtleties correctly (Murray \& Murray, 1986).

Teagarden \& Gordon (1995) conducted a survey of 64 randomly selected vice presidents of human resource, executive directors of international human resources, and vice president of personnel representing large U.S. MNCs operating in the Asian Pacific Rim (Hong Kong, Indonesia, Japan, Malaysia, People's Republic of China, Philippines, Singapore, South Korea, Taiwan, and Thailand). Respondents identified 16 potential expatriate selection criteria (Tables 1 and 2):

\begin{tabular}{|ll|}
\hline \multicolumn{1}{|c|}{ Table 1 Percentage of Selection Criteria Used by MNCs } & Percentages \\
\hline Selection Variable & 100.0 \\
\hline & 97.1 \\
\hline Flexibility & 97.1 \\
\hline Interest in overseas work & 91.2 \\
\hline Technical expertise & 91.2 \\
\hline Knowledge of operations & 88.2 \\
\hline Emotional stability & 85.3 \\
\hline Managerial talent & 85.3 \\
\hline Adaptive family members & 70.6 \\
\hline Assignment is career move & 70.6 \\
\hline Administrative skills & 70.6 \\
\hline Cultural empathy & 67.6 \\
\hline Interest in host culture & 64.7 \\
\hline Stable family relations & 64.7 \\
\hline Communication competence & 58.8 \\
\hline Supportive family members & 47.1 \\
\hline Non-ethnocentrism & \\
\hline Knowledge of language & \\
\hline
\end{tabular}




\begin{tabular}{|lc|}
\hline \multicolumn{1}{|c|}{ Table 2 Mean Rankings of Selection Criteria Importance } & Mean Ranking \\
\hline Selection Variable & \\
\hline & 3.85 \\
\hline Technical expertise & 5.30 \\
\hline Flexibility & 5.52 \\
\hline Managerial talent & 6.30 \\
\hline Emotional stability & 6.90 \\
\hline Cultural empathy & 7.18 \\
\hline Interest in overseas work & 7.94 \\
\hline Adaptive family members & 8.52 \\
\hline Stable family relations & 8.84 \\
\hline Administrative skills & 9.12 \\
\hline Communication competence & 9.55 \\
\hline Supportive family members & 9.97 \\
\hline Non-ethnocentrism & 10.41 \\
\hline Assignment is career move & 11.44 \\
\hline Knowledge of language & 11.45 \\
\hline Interest in host culture & \\
\hline
\end{tabular}

The factors outlined above provide a comprehensive overview of the necessary skills and abilities of an effective expatriate. Analyses of these variables indicate that they could be organized into four categories of criteria for expatriate selection purposes: (1) technical competencies; (2) human relational skills; (3) spouse and family adaptability; and (4) desirability to serve overseas (Table 3).

\begin{tabular}{|ll|}
\hline \multicolumn{2}{|c|}{ Table 3 Expatriate Categories of Selection Criteria } \\
\hline Technical Abilities & Relational Skills \\
\hline Administrative skills & Cultural empathy \\
\hline Knowledge of domestic operations & Emotional stability \\
\hline Domestic managerial talent & Flexibility \\
\hline Technical expertise & Intercultural communication \\
\hline & \\
\hline Family Adaptability & Knowledge of foreign language \\
\hline & Non-ethnocentrism \\
\hline Adaptive family members & Motivational Desirability \\
\hline Stable family relationships & Believe assignment is career move \\
\hline Supportive family members & Interest in overseas work \\
\hline
\end{tabular}

\section{Technical Competencies}

Technical competence, a traditional key selection factor, is one of the primary determinants of success (Hays, 1971). In the international assignment, this expertise may be even more important because the expatriate works far away from headquarters, the hub of technical pool, and cannot easily consult with the colleagues and superiors at home on problems concerning his job (Tung, 1981). The factor is also considered important for expatriate adjustment and satisfaction in the new setting and for the expatriate's ability to effectively transfer information (Mendenhall \& Oddou, 1985; Black, et al, 1992). Knowledge of the company, knowledge of the industry, and managerial talent are all used and regarded as very important for chief executive officers and functional head positions, according to another study (Tung, 1981). For example, a survey conducted by International Orientation Resources found that $90 \%$ of all companies base their international selections on a candidate's technical expertise, followed next by $64 \%$ that also assess a candidate's management ability (Laabs, 1991). This same emphasis on technical ability in the selection process was found in research conducted over 20 years ago and is also found today in European 
research on selection (Bjorkman \& Gertsen, 1993). Still, while business competence appears to be critical for expatriate success, it offers only a partial explanation of success (Teagarden \& Gordon, 1995).

\section{Relational Skills}

In particular, possession of technical/managerial skills may not be sufficient for successful adaptation or for information transfer, which is often considered a key strategic objective. The literature review also suggested that relational skills are important, particularly if the expatriate has significant contact with host nationals (Teagarden \& Gordon, 1995). In domestic operations, this usually refers to the ability of an individual to deal effectively with his superiors, peers, subordinates, business associates, and clients (Tung, 1982). In overseas assignments, this variable greatly influences the probability of successful performance. Because this factor is not only limited to knowledge of another culture, but also includes the ability to relate to, live with and work among people whose value systems, beliefs, customs, manners, and ways of conducting business may be greatly different from one's own (Tung, 1981).

One study found that caring about coworkers and being considerate of others predicted the expatriate's ability to transfer knowledge to host nationals (Kealey, 1989). Another found that avoiding being judgmental and ethnocentric is necessary trait for an expatriate manager (Gudykunst, et al., 1977). Still others advocated that knowledge of people of other cultures, willingness to interact with them, and positive attitudes toward them are indispensable to adjustment and intercultural interaction (Armes \& Ward, 1988; Brandt, 1991; Foxman \& Polsky, 1991; Hammer, 1987, 1978).

There is a considerably high degree of consensus concerning the need for expatriate qualities, such as empathy, flexibility, and open-mindedness (Ruben \& Kealey, 1979; Kealey, 1989; Ronen, 1990). Other characteristics mentioned have included emotional stability, communicative ability, and respect for host countries are all found to be just as important in the selection criteria (Tung, 1981). Apart from communicative ability in the native language, many claim that foreign language mastery is perhaps the greatest single ingredient for an expatriate (Hogan \& Goodson, 1990, Rahim, 1983). Thus, candidates who possess varying degrees of relational skills, in addition to technical skills, would be more likely to be successful expatriates (Teagarden \& Gordon, 1995).

Tung (1981) proposed that if a position required a high degree of interaction with the local community, for instance, a CEO or functional head, and if that community is a highly dissimilar culture from that of the candidate in question, the emphasis of the selection decision should be on relational qualifications. Her conclusion found strong support from many of the U.S. companies surveyed, that identified the significance of the relational skills, despite the fact that only 5 percent of the firms formally assessed them (Teagarden \& Gordon, 1995). In other research studies, reasons of expatriate failure are traced to relational inabilities (Black 1992, 1999; Tung, 1981; Torbiorn, 1982).

Interestingly, much of the expatriate literatures seem to favor selection strategies emphasizing relational abilities. One study identified four important dimensions that related to how well an expatriate adapted to the new environment (Mendenhall \& Oddou, 1985). "Others-oriented" and "perceptual" dimensions have relational implications. The "other-oriented" dimension deals with the expatriate ability to interact well with host nationals through relationship development and a willingness to communicate. The "perceptual" dimension concerns accurate attribution. Well-acculturated expatriates tend to better understand the reasons why and how local nationals may behave under certain circumstance. As a matter of fact, many researchers have concluded that expatriate failure is largely caused by the MNC's negligence to assess a candidate's "knack" for getting along with people of foreign cultures, compounded by an overemphasis on the technical competence criterion (Moran, 1988).

Arguments for the importance of the relation dimension generally focus on the information and feedback that can be obtained from host nationals when developing relationships with them (Mendenhall \& Oddou, 1985). As the expatriate receives more information and feedback from host nationals on appropriate and inappropriate behavior, the expatriate can more readily make behavioral modification and exhibit more culturally appropriate behavior. As the individual exhibits behavior consistent with cultural norms, he receives more positive feedback and as a result, feels more comfortable and adjusted to the new culture (Black, 1990; Black, Mendenhall \& Oddou, 1991). Several empirical studies of people living outside their own culture show a marked connection between the level of 
social interaction and communication with members of the local culture and adjustment (Kealey 1989; Torbiorn, 1982; Rohrlich \& Martin, 1991; Ruben \& Kealey, 1979; Hammer, Gudykunst \& Wiseman, 1978; Brein \& David, 1971; Hawes \& Kealey, 1981).

Therefore, it is believed that MNCs that use an assessment of relational skills in the selection decision would select expatriates who would be more successful. Strong evidence favors a relational-skill-emphasis when selecting expatriates for culturally distant postings, especially when the firm's strategic intent is to achieve greater attainment of market share. The more relational skill is employed in the selection decision making, the higher the percentage of expatriates accomplishing objectives, and the higher the attainments of market share objectives. Equally impressive is the influence of the number of relational skills assessed upon success. The more skills assessed, the lower the percentage of early returns, the higher the percentage of goal achievement, and the higher the attainment of market share objectives (Teagarden \& Gordon, 1995; Tung, 1982).

\section{Family Adaptability}

Bhagat (1983) argued that non-work variables had a spillover impact on expatriates' adjustment and success. An important non-work variable in the success of expatriate performance is the adjustment of family members, as most expatriates are married (Tung, 1988; Black Gregersen \& Mendenhall, 1992). The family's, especially the spouse's ability to adjust to the changes, is highly related to the expatriate's adjustment and to his quality of performance at work (Black, 1988, 1999; Black \& Gregersen, 1991; Black \& Stephens, 1989; Harvey \& Lusch, 1982; Torbiorn 1982; Tung 1982).

Black, Mendenhall and Oddou (1991) argued that it was expected that the uncertainty that would result from poor adjustment of a spouse and children could inhibit the expatriate's adjustment. Janssens (1992) found that social support from the family was most important in facilitating the expatriate's emotional feeling of being adjusted. A family that is poorly adjusted itself is not in a position to provide the expatriate with the social support needed.

Many other researchers and practitioners contended that the adjustment patterns of families also partially determined the expatriate manager's success. The spouse's communication skills, for example, have been associated with the expatriate's success (Tung, 1988). In one survey of executive vice presidents of human resources, the most frequently reported explanation for expatriate failure was poor adjustment of the spouses (Tung 1981).

\section{Motivational Desirability}

Another factor that theoretical and empirical research studies heavily discussed was the expatriate's motives and subsequent motivation to make cross-cultural adjustment (Black \& Gregersen, 1991; Teagarden \& Gordon, 1995; Torbiorn, 1982). Interest in specific host cultures has been linked to expatriate satisfaction, and host-country managers often expect expatriate managers to demonstrate such interest (Armes \& Ward, 1988; Moran, 1988). An expatriate's strong belief in the mission of the posting, in overseas work in general, and a belief that an overseas assignment is a career opportunity have also been described as pertinent to success (Moran, 1988). One study found that expatriates who perceived their postings to have career implications were more successful than those without this awareness (Feldman, 1991). Other studies have found that an expatriate with achievement motivation and positive mission orientation was more likely to remain in the overseas posting, compared with candidates without these characteristics (Hall \& Gudykunst, 1989). Research also shows that self-management techniques enhance the performance of international joint venture general managers (Frayne \& Geringer, 1990). Thus, the more motivated the candidate is to make the transfer and to adjust, the more he/she can be expected to prepare himself/herself for the assignment, and the more likely he/she will be successful in an expatriate posting.

\section{Selection Strategies and Success}

Equally important to the selection decision are the methods used to determine how well the candidate meets the selection criteria. The unidimensional approach, namely technical ability, has been termed "compensatory" approach, and vigorously challenged by many experts in this field (Adler \& Ghadar, 1990; Black, 1991, 1999; 
Dowling \& Schuler, 1990; Mendenhall \& Oddou, 1988; Tung, 1987). This selection methodology has been contrasted with requiring some minimum standard for all dimensions, called a multiple-cutoff approach. Research demonstrates that organizations employing a multiple-cutoff approach experience fewer overseas failures (Newman, Bhatt \& Cutteridge, 1978).

Some of the most influential empirical work on selection approaches has come from studies conducted by Rosalie Tung with 300 of the largest firms listed in Angel's Directory of American Firms Operating Abroad (Tung, 1981). She analyzed the type of selection and training used and expatriate failure rates, as measured by the percentage of early returns. Her findings were that the more rigorously a company selected and trained expatriates across the 18 criteria considered in her study, the less likely that the company's expatriates would fail. She concluded that

In the broader field of organizational theory and management, theorists and researchers who advocate a contingency approach to management have provided evidence to demonstrate the fallacy of applying universal principles or the 'one best way" to management practices, regardless of the situation. In essence, contingency theories argue that the most effective management technique depends upon the set of circumstances at a particular point in time. (p. 68)

\section{Discussion}

The purpose of this paper was to review the existing literature available on selection of the international manager in an attempt to identify criteria that firms have been using for selecting expatriates. Another attempt was made to understand the relationships between a firm's selection strategies and expatriate success. Success was viewed from a multidimensional perspective; four facets of successful expatriate outcomes were examined.

In addition, the tasks and responsibilities of expatriates vary by company, by industry, and by country. An expatriate manager in the service industry, such as the hospitality industry, is likely to have to interact much more extensively with host nationals than would a manager in manufacturing. An expatriate working for a high-profile $\mathrm{MNC}$ is more likely to have to interact with host nationals more extensively than one working for a less visible MNC. Finally, an expatriate information systems manager in a subsidiary would most likely interact much less with locals than would a general manager, a marketing manager, or even a manufacturing manager. The issue here is that, for assessment purposes, expatriates' jobs are not created equal (Teagarden \& Gordon, 1995). Based on what has been found in this study, it is recommended that selection decision-makers should recognize that selection is situation specific and only the first stage in the expatriation process. To maximize the selection process, they should actively seek to assess as many potential criteria of expatriate success as possible with the help of job and situational analyses (Gatewood \& Feild 1998). The more criteria assessed, the more likely the expatriate will be appropriately selected, and thus will be more successful. HR decision-makers that do not assess a candidate's family because it may be invasive and who do not measure relational skills because they may be difficult to determine are less likely to select potentially successful expatriate managers. When making expatriate manager selection decisions, intercultural relational skills should be weighted heavily. This is especially important for expatriate managers who will fill roles that bring them into contact with host nationals, such as general manager, marketing manager, or manufacturing manager. Expatriate managers who understand and interact well with people of the target culture are more likely to be successful in their posting (Teagarden \& Gordon, 1995).

\section{References}

1. Adler, G. (1995). The case of floundering expatriate. Harvard Business Review, July - August, 24 - 40.

2. Adler, N. J. (1987). Pacific Basin Managers: A Gaijin not a woman. Human Resource Management, 26 (2), 169-191.

3. Adler, N. J. \& Ghadar, F. (1990). Strategic human resource management: A global perspective, in R. Piper, ed., Human Resource Management in International Comparison Berlin: de Gruyter, 235-260

4. Armes, K. \& Ward, C. (1988). Cross-cultural transactions and Sojourner Adjustment in Singapore. Journal of Social Psychology, 129 (2), 273 - 275.

5. Baker, J.C. \& Ivancevich, J.M. (1971). The assignment of American executive abroad: systematic, haphazard or chaotic? California Management Review, 50 (4), 31-38.

6. Baliga, G. M. \& Baker J. C. (1985). Multinational corporate policies for expatriate managers: selection and 
evaluation. Advanced Management Journal, 50 (4), 31-38.

7. Beller, M.D. (1995). Yankees, stay home. The Miami Herald, Miami, FL, November 4, Sec. A, 1.

8. Bhagat, R. S. (1983). Effects of stressful life events on individual performance and work adjustment process within organizational settings: a research model. Academy of Management Review, 8 (4), 660 - 671.

9. Bjorkman, I., \& Gertsen, M. (1993). Selection and training Scandinavian expatriates: Determinants of corporate practice. Scandinavian Journal of Management, 9. (2), 154 - 164.

10. Black, J. S. (1988). Work transitions: A study of American expatriate managers in Japan. Journal of International Business Studies, summer, 19 (2), 274-291.

11. Black, J. S. (1990). The relationship of personal characteristics with the adjustment of Japanese expatriate manger. Management International Review, 30 (2), 119 - 134.

12. Black, J.S., Gregersen, H.B. (1991). Antecedents to cross-cultural adjustment for expatriates in Pacific Rim countries. Human Relations, 44, 497-515.

13. Black, J.S., Gregersen, H.B. Mendenhall, M.E. (1990). Cross-cultural training effectiveness: a review and a theoretical framework for future research. Academy of Management Review, 15 (1), 113-136.

14. Black, J.S., Gregersen, H.B. Mendenhall, M.E. (1992). Global assignments: successfully expatriating and repatriating international managers. San Francisco: Josey-Bass.

15. Black, J.S., Gregersen, H.B. Mendenhall, M.E., Stroh, L.K. (1999). Globalizing people through international assignments. Addison-Wesley Longman, Inc., 17.

16. Black, J.S., Mendenhall, M. \& Oddou, G.R. (1991). Toward a comprehensive model of international adjustment: an integration of multiple theoretical perspectives. Academy of Management Review, 6 (2), $262-$ 290.

17. Black, J. S. \& Porter, L. W. (1991) Managerial behaviors and job performance: A successful manager in Los Angeles may not succeed in Hong Kong. Journal of International Business Studies, 22, 99-114.

18. Black, J. S. \& Stephens, G. K. (1989). The influence of the spouse on American expatriate adjustment in overseas assignments. Journal of Management, 15 (4), 529 - 544.

19. Brandt, E. (1991). Global HR, Personnel Journal, March, 38 -44.

20. Brein, M. \& David, K. H. (1971). Intercultural communication and adjustment of the sojourner. Psychological Bulletin, 76, 215 - 230.

21. Chowanec, G. D. \& Newstrom, C. N. (1991). The strategic management of international human resources. Business Quarterly, 52 (2), 65 - 70.

22. Dowling, P. J., Schuler, R. S. (1990). International Dimensions of Human Resource Management, Boston: FIWS-Kent.

23. Dowling, P. J., Schuler, R. S. \& Welch, D. E. (1994). International human resource management: an Australian perspective. Asian Pacific Journal of Management, 6 (1), 39 - 65.

24. Downes, M. (1996) SIHRM: overseas staffing considerations at the environmental level. Journal of International Management, 2 (1), 31-50.

25. Feldman, D. C. (1991). Repatriate moves as career transitions. Human Resource Management Review, 163 $-178$.

26. Feltes, P., Robinson, R.K., and Fink, R.L. (1993). American female expatriates and the Civil Right Act of 1991: Balancing legal and business interests. Business Horizons, March-April, 82 - 86.

27. Foxman L. D. \& Polsky, W. L. (1991). HR approaches to the age of globalization. Personnel Journal, April, 38 - 41.

28. Frayne C. A. \& Geringer, J. M. (1990). The relationship between self-management practice and performance of international joint venture general managers. Proceedings of the Administrative Sciences Association of Canada, 11 (9), 70-79.

29. Gatewood, R. D., Field, H. S. (1998) Human resource measurement in selection. in Human Resource Selection, The Dryden Press: Harcourt Brace College Publisher, 73-110.

30. Giacalone, R. A. \& Beard, J. W. (1994). Impression management, diversity and international management. American Behavioral Scientist, 37 (5), 621 - 636.

31. Gudykunst, W. B., Wiseman, R. L. \& Hammer, M. (1977). Determinants of the Sojourner's attitudinal satisfaction, in B. Ruben, ed., Communication Yearbook I, New Brunswick, NJ: Transaction-Interaction Communication Association.

32. Hall, P. H. \& Gudykunst, W. (1989). The relationship of ethnocentrism in corporate cultures to the selection, training and success of international employees. International Journal of Intercultural Relations, 13, 
183-201.

33. Hammer, M. R., Gudykunst, W. B., \& Wiseman, R. L. (1978). Dimensions of intercultural effectiveness: an exploratory study. International Journal of Intercultural Relations, 2, 382 - 393.

34. Hammer, M. R. (1987). Behavioral dimensions of intercultural effectiveness: a replication and extension. International Journal of Intercultural Relations, 11, 65 - 88.

35. Harvey, M. \& Lusch, R. (1982). Executive stress associated with expatriation and repatriation. Academy of International Business Proceedings, December.

36. Hays, R. D. (1971). Ascribed behavioral determinants of success-failure among U.S. expatriate managers. Journal of International Business Studies, 2, 40-46.

37. Hays, R. D. (1974). Expatriate selection: insuring success and avoiding failure._Journal of International Business Studies, 5, 25 - 37.

38. Hawes, F. \& Kealey, D. J. (1981). An empirical study of Canadian technical assistance. International Journal of intercultural Relations, 5, 239 - 258.

39. Heller, J. E. (1980). Criteria for selecting an international manager. Personnel 57 (3), 47 - 55.

40. Hogan, G. W. \& Goodson, J. R. (1990). The key to expatriate success. Training and Development Journal, January, 50-52.

41. Isobe, T, Makino, S., and Montgomery, D.B. (2000). Resource Commitment, Entry Timing, and market Performance for Foreign Direct Investments in Emerging Economies: The Case of Japanese International Joint Ventures in China. Academy of Management Journal, 43(3), 468-484.

42. Janssens, M. (1992) International job transfers: a comprehensive model of expatriate managers' crosscultural adjustment. Doctoral Dissertation, Catholic University of Leuven, Psychology Department.

43. Kauppinen, M. (1994). Antecedents of expatriate adjustment: A study of Finnish managers in the United States. Helsinki: Center for International Business Research

44. Kealey, D. J. (1989). A study of Cross-cultural effectiveness: theoretical issues, practical applications. International Journal of Intercultural Relations, 13, 387 - 428.

45. Kobrin, S. J. (1989). Expatriate reduction in American Multinationals: Have we gone too far? ILR Report, 27, 22 - 29.

46. Laabs, J. (1991). The global talent search. Personal journal, 70 (8), 38 - 44.

47. Laabs, J. (1993). Rating the international relocation hot spots. Personal Journal, 72, 19.

48. Lanier, Alison. R. (1979). Selecting and preparing personnel for overseas transfers. Personnel Journal, 583, 160-63.

49. Managing on the Frontier (1995). The Economist, June 24, 12-14.

50. Marquart, M.J., \& Engel D.W. (1993). HRD competencies for a shrinking world. Training \& Development, $47(5), 59-65$.

51. Mendenhall, M. \& Oddou, G. (1985). The dimensions of expatriate acculturation: A Review. Academy of Management Review, 10, 39 - 47.

52. Mendenhall, M. \& Oddou, G. (1988). The overseas assignment: A practical look. Business Horizons, September - October, 78 - 84.

53. Mendenhall, M. \& Wiley, C. (1994). Strangers in a strange land. American Behavioral Scientist, 37 (5), $605-620$.

54. Misa, Kenneth F., Fabricatore, Joseph. M. (1979). Return on investment of overseas personnel. Financial Executive, April: 42-46.

55. Moran, R. (1988). Culture shock can be a healthy experience if you roll with the punch. International Management, July - August, 67.

56. Murray, F. T. \& Murray, A. H. (1986). Global managers for global business. Sloan Management Review, winter, $75-80$.

57. Newman, J., Bhatt, B. \& Gutteridge, T. (1978). Determinants of expatriate effectiveness: a theoretical and empirical vacuum. Academy of Management Review, 3 (3), 655-661.

58. Phatak, A. V. (1995). International dimensions of management. Cincinnati, OH: Southwestern, 2.

59. Rahim, A. (1983). A model for developing key expatriate executives. Personnel Journal, 62 (4), 312-317.

60. Ruben, I. \& Kealey, D. J. (1979). Behavioral assessment of communication competency and the prediction of cross-cultural adaptation. International journal of Intercultural Relations, 3, 15-17.

61. Rohrlich, B.F. \& Martin, J. N. (1991). Host country and reentry adjustment of student sojourners. International Journal of Intercultural Relations, Vol. 15, No. 2, 63-82. 
62. Ronen, S. (1990). Training the international assignee," in Goldstein, I., ed., Training and Career Development, San Francisco: Jossey-Bass, 417-451

63. Shumsky, N. J. (1992). Justifying the intercultural training investment. Journal of European Business, 1, 38 $-43$.

64. Sieveking, N. A. \& Marston, R. C. (1978). Critical selection and orientation of expatriates. Personnel Administrator, 23 (4), 20 - 23.

65. Stone, R. J. (1991). Expatriate Selection and Failure. Human Resource Planning, 14 (1), 9 - 18.

66. Teagarden, M. B. \& Gordon, G. D. (1995). Corporate selection strategies and expatriate manager success. Expatriate Management: New Ideas for International Business, Quorum Books, 17 -36.

67. Thompson, J. (1992). Sending employees abroad. Small Business Reports, Vol. 17 (5), 60-64.

68. Torbiorn, I. (1982). Living abroad: Personal adjustment and personnel policy in the overseas setting. New York: Wiley.

69. Tucker, M. F., Baier, V. E., Rhinesmith, S. H. (1985). Before takeoff: what your overseas people need to know. Personnel, December, 60 - 65.

70. Tung, R.L. (1981). Selection and training of personnel for overseas assignments. Columbia Journal of World Business, 16 (1), 68 - 78.

71. Tung, R.L. (1982). Selection and training procedures of U.S. European, and Japanese multinationals. California Management Review, 25 (1), 57 - 71.

72. Tung, R.L. (1984). Strategic management of human resources in the multinational enterprise. Human Resource Management, 23 (2), 129-143.

73. Tung, R. L. (1987). Expatriate assignments: enhancing success and minimizing failure. Academy of Management Executive, 1 (2), 117- 126.

74. Tung, R. L. (1988). The New Expatriates: Managing Human Resources Abroad, Cambridge, MA: Ballinger.

75. Zachary, P.G. (1996) Strategic shift: major U.S. companies expand efforts to sell to consumers abroad. The Wall Street Journal, (New York, NY) June 13, Sec. A. 1.

76. Zeira, Y. \& Banai, M. (1985). Selection and expatriate managers in MNCs: The host country point of view. International Studies of Management and Organization, 33-51. 